Streamlining Pension Contributions in the People's Republic of China

\title{
理顺中国的养老金缴费体系
}





\section{Streamlining Pension Contributions in the People's Republic of China 理顺中国的养老金缴费体系}


(c) 2020 Asian Development Bank

6 ADB Avenue, Mandaluyong City, 1550 Metro Manila, Philippines

Tel +6328632 4444; Fax +63286362444

www.adb.org

Some rights reserved. Published in 2020.

ISBN 978-92-9262-057-8 (print), 978-92-9262-058-5 (electronic)

Publication Stock No. BRF200086-2

DOI: http://dx.doi.org/10.22617/BRF200086-2

The views expressed in this publication are those of the authors and do not necessarily reflect the views and policies of the Asian Development Bank (ADB) or its Board of Governors or the governments they represent.

$A D B$ does not guarantee the accuracy of the data included in this publication and accepts no responsibility for any consequence of their use. The mention of specific companies or products of manufacturers does not imply that they are endorsed or recommended by ADB in preference to others of a similar nature that are not mentioned.

By making any designation of or reference to a particular territory or geographic area, or by using the term "country" in this document, ADB does not intend to make any judgments as to the legal or other status of any territory or area.

This work is available under the Creative Commons Attribution 3.0 IGO license (CC BY 3.0 IGO)

https://creativecommons.org/licenses/by/3.0/igo/. By using the content of this publication, you agree to be bound by the terms of this license. For attribution, translations, adaptations, and permissions, please read the provisions and terms of use at https://www.adb.org/terms-use\#openaccess.

This CC license does not apply to non-ADB copyright materials in this publication. If the material is attributed to another source, please contact the copyright owner or publisher of that source for permission to reproduce it.

ADB cannot be held liable for any claims that arise as a result of your use of the material.

Please contact pubsmarketing@adb.org if you have questions or comments with respect to content, or if you wish to obtain copyright permission for your intended use that does not fall within these terms, or for permission to use the ADB logo.

Corrigenda to ADB publications may be found at http://www.adb.org/publications/corrigenda.

Note:

In this publication, "\$” refers to US dollars.

ADB recognizes "China" as the People’s Republic of China.

\section{(c) (1)}

(C) 亚洲开发银行 2020

City, 1550 Metro Manila, Philippines （菲律宾马尼拉）

4444; 传真 +63286362444

www.adb.org

部分版权所有。2020 年出版。

ISBN 978-92-9262-057-8 (印刷版), 978-92-9262-058-5 (电子版)

出版物库存号: BRF200086-2

DOI: http://dx.doi.org/10.22617/BRF200086-2

本出版物中所述为作者个人观点, 并不代表亚洲开发银行（亚行）、亚行理事会或其所代表的政府的观点和政策。

亚行不担保本出版物中所含数据的准确性, 而且对使用这些数据所产生的后果不承担任何责任。本出版物中提及特定公司或厂商产品并不意味着亚行认 为其优于未提及的类似性质的公司或厂商产品, 并予以认可或推荐。

在本出版物中指称或引用某个特定版图或地理区域时, 或使用 “国家”一词时, 不代表亚行意图对该版图或区域的法律地位或其他地位做出任何评判。

本出版物采用 “政府间组织3.0版知识共享许可协议” (CC BY 3.0 IGO) http://creativecommons.org/licenses/by/3.0/igo/。使用该出版物中的内容即 表示同意遵守上述许可协议的条款。有关署名、翻译、修改和权限的信息, 请参阅https://www.adb.org/terms-use\#openaccess中的规定和使用条款。

本知识共享许可不适用于本出版物中非亚行版权的资料。如某资料另有来源, 请联系该资料的版权所有人或出版人获得复制许可。亚行对因使用此类资 料所产生的任何索赔不承担责任。

如对本出版物内容有任何疑问或建议, 或希望就不适用于上述条款的预期用途获得版权许可, 或申请亚行标识的使用许可,

请联系pubsmarketing@adb.org。

亚行出版物勘误信息可在以下网页查询: http://www.adb.org/publications/corrigenda。

注: 在本出版物中, “\$”表示美元。

亚行承认”中国“为 “中华人民共和国”。

译文声明

为扩大读者范围, 特将本出版物由英文翻译为中文。亚洲开发银行 (亚行) 尽力确保翻译的准确性, 但英语是亚行的官方语言, 因此, 本出版物的英文 原版是唯一合法的 (即官方的和经授权的) 文本。任何对本出版物内容的引用, 必须以其英文原版内容为准。 
Streamlining Pension Contributions in the People's Republic of China

\section{理顺中国的养老金缴费体系}

\section{Abstract} 摘要

- An inaccurate contribution base has been a long-standing problem in collecting basic pensions in the People's Republic of China (PRC), where underreporting leads to significant shortfalls. Moreover, pension contribution rates are set by each province and the collected contributions are pooled within provinces, which limits the transferability of pensions nationwide and inhibits labor mobility. Against this background, the current pension contribution system in the PRC faces two main challenges: determining the pension contribution base and setting the pension contribution rates.

长期以来, 中华人民共和国 (中国) 在征缴基本养老金方面存在着缴费基数不清的问题, 而低报则导 致养老金账户出现巨大缺口。此外, 养老金缴费率由各省确定, 且缴存的养老金集中在各省, 这不仅 限制了养老金在全国范围内的转移, 也抑制了劳动力的流动。在这一背景下, 中国现行的养老金缴费 制度面临两大挑战: 确定养老金缴费基数和设定养老金缴费率。

- Determining the contribution base remains difficult for six reasons: (i) the entrance thresholds of the contribution base vary by region, (ii) the definition of indicators to determine the average employee salary used for calculating the contribution remains unclear, (iii) using the average employee salary as the only indicator to collect and pay pensions leads to a choice dilemma, (iv) obstacles exist in collecting pension contributions, (v) difficulties in verifying the contribution base lead to an inaccurate base, and (vi) inadequate auditing of employers leads to enterprises circumventing regulations.

目前在确定缴费基数方面仍然存在一定困难, 主要有六个方面的原因: (1) 各地的缴费基数下限存 在差异; (2) 在确定用于计算缴费的职工平均工资方面所使用的指标定义不清晰; (3) 将职工平均工 资作为养老金征缴和发放的唯一指标, 导致选择困境; (4) 养老金缴费征缴存在困难; (5) 在核查缴 费基数时面临诸多困难, 导致缴费基数不准确; 以及 (6) 稽核不力导致部分企业违规。

- There are two difficulties in setting pension contributions rates: (i) employer contributions are not pooled at the national level, and (ii) there is competition between local governments to attract foreign investment through lower contribution rates.

在确定养老金缴费率时, 面临两大困难:（1）企业缴费未实现国家统筹; 以及 (2) 各地政府之间存在 竞争, 通过降低缴费率来吸引外资。

- Although the government has adopted important reforms, including lowering the employer pension contribution in March 2019, further actions are needed. This policy note suggests the following measures: (i) consolidate the contribution base while stabilizing the level of government subsidies to the basic pension; (ii) reform the method for determining the contribution base and achieve national pooling; and (iii) establish an interagency information exchange network.

为应对上述挑战, 中国政府实施了多项重大改革, 并于2019年3月下调企业养老金缴费率, 但这些措 施还远远不够。本政策简报建议采取以下措施:（1）在稳定政府对基本养老金补贴水平的同时, 巩固 养老金缴费基数;（2）改革养老金缴费基数确定办法, 并实现养老金的全国统筹; 以及 (3) 建立跨部 门信息交流网络。 


\section{观察与建议}

\section{BACKGROUND}

1. In July 2018, the General Office of the Communist Party of China Central Committee and the General Office of the State Council promulgated the Reform Plan of Collection and Management of National Tax and Local Tax. The plan specified that various social security contributions (SSCs), including for basic pension, basic medical care, unemployment insurance, work-related injury insurance, and maternity insurance, would be uniformly collected by the State Taxation Administration from 1 January 2019. Collection by the State Taxation Administration, instead of the Ministry of Human Resources and Social Security (MOHRSS), will improve the capacity and efficiency of SSC collection and management, and will help close loopholes in previous collection and management practices, thereby promoting social equity.

2. However, the plan has raised concern among some enterprises, which consider the proposed changes burdensome. In response, the relevant government departments have decided to temporarily suspend the implementation of tax collection decisions and collect SSCs using the original collection measures. An inaccurate contribution base has been a long-standing, unresolved problem in collecting SSCs, particularly for basic pensions, where underreporting leads to significant shortfalls. This problem must be solved, and to do that, a systematic analysis of its reasons is needed to offer feasible solutions.

3. In March 2019, the Government of the People's Republic of China (PRC) announced a rate cut for employers' pension contributions, reducing the rate from $19 \%-20 \%$ to a maximum of $16 \%$ of the wage bill. Although this cut is a step in the right direction, other issues remain. For example, pension contribution rates are set by each province and the collected contributions are pooled within provinces, which limits the transferability of pensions nationwide and inhibits labor mobility. Addressing the problems of underreporting and nationwide pooling is essential to enhance efficiency and create room to lower nominal contribution rates, which would help employers actually make the set contributions without having to bear a significant additional financial burden. Based on international experiences, this policy note offers recommendations to that effect.

\section{MAIN ISSUES PERTAINING TO PENSION CONTRIBUTIONS FOR URBAN EMPLOYEES}

4. The current system in the PRC faces challenges in two main areas: determining the pension contribution base, and setting the pension contribution rates. 


\section{A. Determining the Pension Contribution Base}

5. Because of complex verification procedures, the accounting standards of some indicators used for determining the pension contribution base are not standardized. Meanwhile, a degree of autonomy in setting the contribution base leads to a great difference in the actual implementation of the contribution base among different regions. To reduce their contributions, companies often underreport employee salaries to the MOHRSS, which is not able to check the reports because it has no access to tax data. According to a 2018 white paper on social security, only $27 \%$ of the surveyed enterprises paid full SSCs according to their employees' actual salaries. ${ }^{1}$ Determining the contribution base remains difficult for six reasons (paras. 6-11).

6. First, the entrance thresholds of the employee contribution base vary by region. According to a 2018 report by China Labor Watch, in 31 major cities-14 of which are provincial capitals-the ceiling of the contribution base was $300 \%$ of the average of local employee salaries in the previous year. ${ }^{2}$ However, the determination of the entrance threshold of the contribution base in these cities differed as follows:

(i) In 19 cities, $60 \%$ of the average of the local employee salary in the previous year was used as the entrance threshold, strictly implementing government policies and regulations.

(ii) In seven cities, about $50 \%$ of the average local employee salary in the previous year was used as the entrance threshold.

(iii) In three cities, about $40 \%$ of the average local employee salary in the previous year was used.

(iv) In two cities, a specific value was stipulated as the entrance threshold of the contribution base using the average local employee salary in the previous year.

7. Second, the contribution base is determined by the average employee salary, but this average is confusingly defined. In central government documents, different terms are used, such as "the average local employee salary" and "the average local on-the-job employee salary." At the local government level, multiple indicators are used, such as "the average on-the-job employee salary in non-private sectors in urban areas," "the average employee salary in the urban non-private sector," "the average salary of legal entities in a city," and "the average salary in a city." The multiple definitions lead to different ways of calculating the average employee salary across locations.

1 C. Siwei, Y. Hairong, and H. Wei. 2018. In Depth: China's Social Security Balancing Act. Caixin online. 27 August.

2 China Labor Watch. 2019. 2018 Social Insurance Rates in China. 


\section{观察与建议}

8. Third, using the average employee salary as the only indicator to collect pension contributions and pay pensions leads to a choice dilemma. The average employee salary is not only an important referential index for determining the employee contribution base, but also the basis for determining pensions. Contributors want to pay in as little as possible, while retirees hope that the average pay of employees is as high as possible to receive higher pensions. Therefore, in some areas, the smaller

"average employee salary citywide" is used to determine the contribution base, but the larger "average on-the-job employee salary citywide" is adopted for pensions.

9. Fourth, there are two common challenges with employees' pension contributions: (i) actual pension contributions are often close to the lowest possible amount, and (ii) low-income earners have to pay high contributions. In the first case, a large number of employees only contribute at the entrance threshold of the local contribution base. In the second case, low-income earners whose salaries are below the entrance threshold of the local contribution base have to make SSCs based on the threshold of the local contribution base.

10. Fifth, the complex content and difficult task of verifying the contribution base lead to an inaccurate base. Because of different regulations promulgated by the National Bureau of Statistics and the accounting regulations and standards adopted by different enterprises, it is difficult to classify some fringe benefits strictly by the wage composition, resulting in underreporting and concealment. Furthermore, the Regulations on the Composition of Gross Wages, 1990 specify the wage composition in great detail, while the National Bureau of Statistics regularly modifies related provisions on total salary. It is therefore challenging for the MOHRSS to approve contribution wages every year.

11. Sixth, inadequate auditing often leads to enterprises circumventing regulations. When the MOHRSS collects pension contributions, the accuracy of the contribution base is determined by auditing. However, because of asymmetric information and an insufficient number of auditors, the ministry has curtailed auditing measures, relying instead on employee complaints to become active. In case a false contribution base is found, the MOHRSS would resolve it by negotiating with the employer.

\section{B. Setting Pension Contributions Rates}

12. The level of social security contribution pooling is low. Although the central government incorporated the goal of national pooling for the urban basic pension into the Thirteenth Five-Year Plan, 2016-2020, it is unlikely to be achieved by the end of 2020. At present, only provincial pooling (i.e., the provincial governments are responsible for the collection, payment, and management of their basic pensions) has been achieved, and in some provinces only nominal pooling or an intra-provincial adjustment has been set. Although the central government has promulgated clear policies on the 
basic pension insurance system, enforcement remains weak. As a result, once an imbalance occurs and local governments face financial constraints in paying the social security fund, they have to turn to the central government for support. In the opposite case, if revenues exceed expenditures at the local level, local governments tend to lower the contribution rate, thereby breaching the rules.

13. Another challenge stems from attempts of local governments to attract foreign investment through lower contribution rates. This is possible when the local security fund receives more than it disburses. This results in well-developed regions having adequate social security funds while poorer regions do not. By reducing SSCs, more foreign investment can be attracted, creating more jobs. This in turn attracts a younger labor force and increases the collection of social security funds. By contrast, regions with insufficient social security funds are normally less developed economically and are not able to reduce the contribution rate. A higher contribution rate hampers their efforts to attract foreign investment and drives out existing enterprises, capital, and labor, further reducing social security funds. This causes large differences among provinces. For instance, before May 2019, the employers' contribution rate was $14 \%$ in Guangdong and $20 \%$ in Heilongjiang.

\section{POLICY RECOMMENDATIONS}

14. While reducing employer pension contribution rates was a first step in reforming the SSC system, the contribution base remains small and rates remain high. Other issues in the current system include low efficiency in SSC collection and the underreporting of employee salaries by employers. To further reform the system, steps are needed in three directions: (i) further reducing the burden on enterprises, while keeping government subsidies manageable; (ii) enhancing collection efficiency and pooling; and (iii) improving information exchange to minimize misreporting.

\section{A. Reducing the Burden on Companies While Keeping Government Subsidies Manageable}

15. Consolidate the contribution base and further reduce the contribution rate. For any given amount of contribution, there is a trade-off between the contribution base and rate. Once the current contribution base is consolidated, the contribution rate can be reduced further. The current employer rate of contribution is still high because the contribution base is not accurate. To consolidate the contribution base, the authority for SSC collection should be transferred from the MOHRSS to the State Taxation Administration, to which salaries are reported for tax purposes. This would make systematic underreporting more difficult.

16. Stabilize the level of government subsidies to the basic pension insurance. Without government subsidies, the PRC's national pension fund for urban employees should have been in deficit since 2015. Moreover, the Chinese Academy of Social Sciences estimated that local 


\section{观察与建议}

pension funds in 16 provinces would be in deficit in 2019, even with fiscal transfers from the central government. Under the current pension system, government subsidies should be increased to compensate for the inadequate collection of pension contributions. However, rapidly increasing government subsidies to the basic pension will add pressure on public finances. For example, the Government of Japan increased the ratio of government subsidies to the basic pension from onethird to one-half in 2009 , causing an increase in subsidies paid from $1.5 \%$ of gross domestic product (GDP) in 2008 to $2.0 \%$ of GDP in 2009. Since then, it has remained broadly unchanged and stood at $2.1 \%$ of GDP in 2018. Considering that in the PRC the government subsidy to the basic pension for urban employees reached $1.0 \%$ of GDP in 2018, the level should be kept under $1.5 \%$ of GDP in the next 5 years.

\section{B. Enhancing Collection Efficiency and Pooling}

17. Reform the method for determining the contribution base in two steps. The first step is to determine the scope of wages used for calculating SSCs. The scope of wages used for SSC calculations should differ by type of organization. For enterprises, as their employees' salary often consists of different components, the focus should be on the main part of the remuneration as the basis for the verification of the wages. Since the pay structure for government agencies and institutions is relatively clear, it is possible to use all the items incorporated in the salary for calculating the SSC. For freelancers, it is advisable to set the local minimum contribution as a common standard when integrating them into the basic pension contributions for urban employees.

18. The second step is to set the minimum wage standard as the minimum contribution base and to use the current month's salary as the regular contribution base for SSC calculations. The minimum wage standard, which is published in various regions, constitutes the minimum pay. Therefore, the minimum wage standard should be adopted as the local minimum contribution base. Employees contribute to the pension insurance in line with their own monthly wage. By separating the contribution base from the local average wage, employees will contribute based on their actual wage, thereby solving the problem of low income but high contribution. Meanwhile, it is necessary to retain $300 \%$ of the local average wage as a ceiling on the contribution base. This figure is reasonably close to the average of the ceilings (224\%) for 20 countries within the Organisation for Economic Cooperation and Development (OECD) in $2016 .^{3}$

3 OECD. 2017. Pensions at a Glance 2017: OECD and G20 Indicators. Paris: OECD Publishing. 
19. Achieve national pooling for the basic pension system for urban employees. To move to national polling of the basic pension system, two measures are recommended: (i) clarify the financing and payment responsibilities between the central and local governments, delineating their rights and obligations clearly; and (ii) establish a unified information platform and a national actuary system to consolidate provincial data and to develop a realistic implementation plan for the pooling.

\section{Improving Information Exchange to Minimize Misreporting}

20. Establish an interagency information exchange network to avoid fraud or misreporting. By establishing a three-party information exchange platform-including government agencies in charge of social security, taxation, and the banking system - the effectiveness and efficiency of supervision of pension collection and management can be improved. Sweden is a good example in setting a fully integrated network for collecting and managing SSCs, including pension contributions. In the mid1980s, the Swedish Tax Agency was assigned responsibility for collecting SSCs using a national computer system. Today, personal identity numbers are used in this system so that information can be easily shared with the Swedish Social Insurance Agency. SSCs are collected from employers, who make payments into the Swedish Tax Agency's bank account. 


\section{观察与建议}

\section{一、背景}

1. 2018年7月, 中共中央办公厅、国务院办公厅印发了《国税地税征管体制改革方案》。方案规定, 从2019年1月1日起, 将基本养老保险费、基本医疗保险费、失业保险费、工伤保险费、生育保险费等各 项社会保险费 (社保) 交由国家税务总局统一征收。由国家税务总局代替人力资源和社会保障部 (人 社部) 对社保进行征收, 将提高社保征管能力和效率, 弥补以往征管工作的不足, 促进社会公平。

2. 然而, 部分企业担心, 方案中拟议的改革将大幅增加企业负担。为此, 有关政府部门已决定暂停 实施由税务机关征收的决定, 继续按原办法征收社保。中国在征收社保, 特别是基本养老金方面长期 面临的缴费基数不准确问题一直未得到解决, 而低报问题又导致养老金账户出现巨大缺口。为从根本 上解决这一问题, 需要对相关原因进行系统分析, 进而提出具备可操作性的解决方案。

3. 2019年3月, 中国政府宣布下调企业养老金缴费率, 将其由工资的19\% 20\%最大下调至16\%。虽 然采取了下调养老金缴费率这一行之有效的措施, 但仍然存在其他问题。例如, 养老金缴费率由各 省确定, 且缴存的养老金集中在各省内, 这不仅限制了养老金在全国范围内的转移, 也抑制了劳动力 流动。解决低报和全国统筹问题对于提高征管效率以及为下调养老金名义费率创造空间来说至关重 要。如此一来, 企业就可以根据设定的较低费率如实缴费, 无需承担过多的经济压力。本政策简报基 于国际经验, 提出了实现上述目标的相关建议。

\section{二、城镇职工养老金缴费中存在的主要问题}

4. 中国的现行制度主要面临以下两个方面的挑战:（1）确定养老金缴费基数;（2）设定养老金缴费 率。

\section{（一）确定养老金缴费基数}

5. 由于核查程序复杂, 确定养老金缴费基数所用的部分指标存在核算标准不规范的问题。同时, 各 地在设定缴费基数上拥有一定的自主权, 导致不同地区实际执行的缴费基数存在较大差异。为减少 缴费额, 企业经常向人力资源和社会保障部低报职工工资, 后者由于难以获得纳税数据, 无法核查报 告。据2018年社保白皮书显示, 仅有 $27 \%$ 的受访企业根据职工实际工资全额缴纳社保。 ${ }^{1}$ 导致缴费基 数确定困难有以下六大原因（第6-11段）。

6. 第一, 各地的缴费基数下限存在差异。《中国劳工观察》发布的2018年报告显示, 在31个主要城市 (其中14个是省会城市) 中, 缴费基数上限是当地职工上年平均工资的 $300 \%$ 。 ${ }^{2}$ 但是, 在确定缴费基 数下限时, 各城市间存在着以下差异:

1 C. Siwei, Y. Hairong和H. Wei, 2018年。In Depth: China’s Social Security Balancing Act. 财新网。8月27日。

2 《中国劳工观察》, 2019年, 2018 Social Insurance Rates in China. 
Streamlining Pension Contributions in the People's Republic of China

理顺中国的养老金缴费体系

(1) 有19个城市严格按照政府政策和法规要求, 将当地职工上年平均工资的 $60 \%$ 作为下限。

（2）有7个城市将当地职工上年平均工资的约 $50 \%$ 作为下限。

(3) 有 3 个城市将当地职工上年平均工资的约 $40 \%$ 作为下限。

(4) 有 2 个城市按照规定的有关当地职工上年平均工资的一个具体数值作为下限。

7. 第二, 虽然缴费基数根据职工平均工资来确定, 但关于平均工资的定义并不清晰。中央政府文件 中使用的术语不尽相同, 如 “当地职工平均工资”、“当地在岗职工平均工资” 等。地方政府则采用了 多个指标, 如 “城镇非私营单位在岗职工平均工资”、“城镇非私营单位职工平均工资”、“某市法人单 位平均工资”、“某市平均工资” 等。各种不同定义导致不同地区计算职工平均工资的方法存在差异。

8. 第三, 使用职工平均工资作为确定养老金征缴和发放的唯一指标, 导致选择困境。职工平均工 资既是确定职工缴费基数的重要参考指标, 也是确定养老金领取的依据。缴费者希望支付的越少越 好, 而对于退休人员来说, 职工平均工资越高, 他们获得的养老金就越多。因此, 某些地区选择使用 较低的 “全市职工平均工资” 和较高的 “全市在岗职工平均工资” 来分别确定缴费基数和养老金领取 依据。

9. 第四, 职工在缴纳养老金时面临两个共同的挑战: (1) 实际的养老金缴费往往接近可能的最低数 额; (2) 低收入者必须缴纳较高的数额。在第一种情况下, 有很多员工只按照当地缴费基数下限缴纳 一定数额。在第二种情况下, 工资低于当地缴费基数下限的低收入者必须根据当地缴费基数下限来 缴纳社保。

10. 第五, 由于核查缴费基数涉及的内容复杂, 任务艰巨, 导致了缴费基数不准确。由于国家统计局 颁布的法规不同, 各企业采用的会计法规和标准也不一致, 因此, 很难严格按照工资构成对福利性收 入进行分类, 导致低报和瞒报。此外, 1990年颁布的《关于工资总额组成的规定》对工资构成规定太 过详细, 此后国家统计局还经常对工资总额的相关规定做出调整。因此, 每年核定应缴费工资对人社 部来说是一项挑战。

11. 第六, 稽核不力经常导致企业违规。人社部征收养老金缴费时, 缴款基数的准确与否取决于审 计。然而, 由于信息不对称和审计人员数量不足, 人社部用员工举报代替了部分审计措施, 希望能发挥 一定作用。如发现缴费基数不实, 人社部将只能和企业通过谈判的方式解决。

\section{（二）设定养老金缴费费率}

12. 社保缴费的统筹层次低。虽然中央政府将实现城镇基本养老金全国统筹的目标纳入了 “十三五” 规划 (2016年一2020年), 但这一目标在2020年年底前不大可能实现。目前, 仅实现了省级统筹, 即, 省级政府负责基本养老金的征收、支付和管理。部分省份仅确定了名义上的统筹或省内调整。中央政 府出台了有关基本养老保险制度的明确政策, 但政策执行力度依然薄弱。这样一来, 在出现社保基金 


\section{观察与建议}

收不抵支、面临支付压力的地方, 当地政府不得不向中央政府寻求支持。另一方面, 在那些社保基金 收入超出支出的地方, 当地政府会违规降低缴费费率。

13. 另一个挑战在于地方政府试图通过降低缴费率来吸引外资。在那些社保基金收大于支的地方, 这有可能实现。但同时也会导致越发达的地区社保基金就越充足, 而越贫困的地区社保基金就越不 足的情况。通过降低社保缴费, 可吸引更多外资, 创造更多就业机会。这反过来又吸引了更年轻的劳 动力, 增加了社保基金收入。相比之下, 社保基金不足的地区通常是经济欠发达地区, 而这些地区难 以降低缴费率。缴费率提高不仅不利于吸引外资, 还会排挤现有企业、资本和劳动力, 导致社保基金 减少, 扩大各省之间的差异。例如, 在2019年5月前, 广东的企业社保缴费率为 $14 \%$, 黑龙江为 $20 \%$ 。

\section{三、政策建议}

14. 虽然降低雇主养老金缴费率在社保制度改革方面迈出了第一步, 但缴费基数仍然很小, 缴费率 居高不下。现行制度中存在的其他问题包括社保征收效率低下、企业低报职工工资等。为深入推进养 老金制度改革, 需要从以下三方面着手: (1) 进一步减轻企业负担, 同时维持政府补贴在一定规模;

(2) 提高征收效率, 促进全国统筹; (3) 完善信息交流, 尽可能减少谎报。

\section{（一）进一步减轻企业负担, 同时维持一定规模政府补贴。}

15. 巩固缴费基数, 进一步下调缴费率。养老金总征缴额一旦确定, 缴费基数和缴费率之间就是此消 彼长的关系。只要缴费基数坐实, 缴费率可进一步下调。由于缴费基数不准确, 现行企业缴费率仍然 偏高。为坐实缴费基数, 应将社保征收的权力从人社部转移到国家税务总局, 后者收集工资数据用于 征税目的, 此举将使降低系统性低报变得困难。

16. 稳定政府对基本养老保险的补贴水平。如缺少政府补贴, 中国城镇职工的国家养老基金自2015 年起就会出现赤字。另外, 据中国社会科学院估计, 即使有中央政府的财政转移支付支持, 仍会有16 个省份的地方养老基金在2019年出现赤字。在现行养老金制度下, 应通过增加政府补贴来缓解养 老金缴费不足的压力。然而, 政府对基本养老金的补贴增长过快, 将加重公共财政压力。例如, 2009 年日本政府将对基本养老金的政府补贴率从 $33 \%$ 左右提高至 $50 \%$, 导致所支付补贴占国内生产总值

(GDP) 的比重从2008年的 $1.5 \%$ 提高到 2009 年的 $2.0 \%$ 。此后, 这一比例基本保持不变, 2018 年为 $2.1 \%$ 。2018年, 中国政府对城镇职工基本养老金的补贴占GDP的比例达到 $1.0 \%$ 。在未来 5 年, 应将这 一比例控制在 $1.5 \%$ 以内。

\section{（二）提高征收效率，促进全国统筹。}

17. 分两步改革缴费基数确定办法。第一步, 确定用于计算社保的工资范围。在确定这一范围时, 应 考虑到不同的组织类型。对于企业来说, 职工薪酬往往形式多样, 因此应重点关注薪酬的主体部分, 
理顺中国的养老金缴费体系

将其作为工资核定的依据。相比之下, 政府机构的薪酬结构较为清晰, 因此可将所有工资项作为计算 社保的依据。对于自由职业者来说, 建议他们在缴纳城镇职工基本养老金时, 使用当地最低缴费标 准作为通用标准。

18. 第二步, 将最低工资标准设为最低缴费基数, 并使用当月工资作为缴纳社保的常用缴费基数。各 地颁布的最低工资标准包含最低薪酬。因此, 应将最低工资标准作为当地最低缴费基数。员工按照 自己的月薪缴纳养老保险。将缴费基数和当地平均工资脱钩, 员工将根据实际工资缴费, 从而解决了 低收入者缴费过高的问题。同时, 缴费基数上限有必要继续沿用当地平均工资的 $300 \%$ 。这一数字和 2016年经济合作与发展组织 (经合组织) 中20个成员国的平均上限 (224\%) 比较接近。

19. 实现对城镇职工基本养老金制度的全国统筹。为推动基本养老金制度的全国统筹, 建议采取 以下两项措施：(1) 明确中央和地方政府之间的收入和支付责任, 明确界定双方的权利和义务; 以及

(2) 通过建立统一的信息平台和国家精算体系, 整合各省数据, 制定切实可行的统筹实施方案。

\section{（三）完善信息交流，尽可能减少谎报。}

20. 建立跨部门信息交流网络, 避免欺诈或瞒报。建立包括社保、税收、银行系统在内的三方信息交 流平台, 提高养老金征管监督的有效性和效率。瑞典建立了涵盖养老金缴费的社保征管综合网络, 做 出了良好示范。自20世纪80年代中期以来, 瑞典税务局就负责使用国家计算机系统征收社保。时至 今日, 该系统通过使用个人身份号码, 很轻松地实现了与瑞典社会保险局的信息共享。而瑞典的企业 则通过瑞典税务局的银行账户进行社保缴费。

3 经合组织, 2017年。Pensions at a Glance 2017: OECD and G20 Indicators. 巴黎: 经合组织发布。 


\title{
Streamlining Pension Contributions in the People's Republic of China
}

The current pension contribution system in the People's Republic of China faces two main challenges: determining the pension contribution base and setting the pension contribution rates. Although the government has adopted important reforms, including lowering the employer pension contribution in March 2019, further actions are needed.

This policy note suggests the following measures: (i) consolidate the contribution base while stabilizing the level of government subsidies to the basic pension; (ii) reform the method for determining the contribution base and achieve national pooling; and (iii) establish an interagency information exchange network.

\section{About the Asian Development Bank}

ADB is committed to achieving a prosperous, inclusive, resilient, and sustainable Asia and the Pacific, while sustaining its efforts to eradicate extreme poverty. Established in 1966, it is owned by 68 members -49 from the region. Its main instruments for helping its developing member countries are policy dialogue, loans, equity investments, guarantees, grants, and technical assistance.

\section{理顺中国的养老金缴费体系}

中国现行的养老金缴费体系面临两大挑战: 确定养老金缴费基数和设定养老金缴费率。为应对上述挑战, 中国政府实施了多项重大改革, 并于2019年3月下调企业养老金缴费率, 但这些措施还远远不够。

本政策简报建议采取以下措施：（1）在稳定政府基本养老金补贴水平的同时, 坐实养老金缴费基数;

（2）改革养老金缴费基数确定办法, 实现全国统筹;（3）建立跨部门信息交流网络。

\section{关于亚洲开发银行}

亚行在坚持消除极端贫困的同时, 致力于实现繁荣、包容、有适应力和可持续的亚太地区。亚行成立 于1966年, 现有68个成员, 其中49个来自亚太地区。亚行主要通过政策对话、贷款、股权投资、担 保、赠款以及技术援助等工具向发展中成员体提供帮助。

$\mathrm{ADB}$

\section{ASIAN DEVELOPMENT BANK}

6 ADB Avenue, Mandaluyong City 1550 Metro Manila, Philippines www.adb.org

\author{
亚洲开发银行驻中国代表处 \\ 北京朝阳区建国门外大街1号 \\ 国贸大厦A座17层 \\ 邮编: 100004 \\ www.adb.org/prc \\ cn.adb.org
}

